\title{
PENERAPAN STRATEGI PEMBELAJARAN COLLEGE BALL UNTUK MENINGKATKAN AKTIVITAS DAN HASIL BELAJAR PESERTA DIDIK PADA MATERI LARUTAN PENYANGGA
}

\author{
Sarinemsih ${ }^{1}$ 1, Erviyenni ${ }^{1}$, Johni Azmi ${ }^{1}$ \\ 1 Universitas Riau, Jalan Bina Widya KM 12.5, Simpang Baru, Kec. Tampan, Kota Pekanbaru, \\ Riau 28293
}

\begin{abstract}
Abstrak - Penelitian ini bertujuan untuk mengetahui apakah strategi pembelajaran aktif College Ball dapat meningkatkan aktivitas dan hasil belajar peserta didik pada materi kesetimbangan ion dan $\mathrm{pH}$ larutan penyangga. Jenis penelitian ini adalah penelitian tindakan kelas dengan menggunakan 3 siklus dan dilaksanakan pada salah satu sekolah SMA Negeri di Pekanbaru, Riau. Setiap siklus terdiri atas dua proses belajar mengajar yang masing-masing mencakup empat tahap yaitu: perencanaan, pelaksanaan, observasi, dan refleksi. Hasil penelitian menunjukkan bahwa strategi pembelajaran aktif College Ball dapat meningkatkan aktivitas bertanya dan menjawab pertanyaan peserta didik serta hasil belajar mereka dalam pembelajaran larutan penyangga.
\end{abstract}

Kata kunci: Strategi pembelajaran aktif College Ball, aktivitas belajar, dan hasil belajar

\begin{abstract}
The research aimed to improve the students' learning activity and achievement on buffer solutions topic using College Ball learning strategy. This research was a classroom action research design consisting of three cycles and was conducted at a public secondary school in Pekanbaru, Riau. Each cycle was carried out in two meetings with four stages (planning, implementation, observation, and reflection) in each. The results showed that College Ball's active learning strategy increased the students' learning activity and achievement on the topic of of buffer solution.
\end{abstract}

Keywords: College Ball learning strategy, learning activity, student's achievement

\section{PENDAHULUAN}

Belajar sangat penting bagi setiap orang guna mendapatkan ilmu pengetahuan. Belajar merupakan proses pembentukan pengetahuandi mana peserta didik aktif melakukan kegiatan belajar, aktif berpikir, menyusun konsep dan memberi makna tentang hal-hal yang sedang dipelajarinya (Suprihatiningrum, 2016). Keberhasilan belajar peserta didik ditandai oleh tercapainya Kriteria Ketuntasan Minimal (KKM). Salah satu SMAN di Pekanbaru menetapkan KKM mata pelajaran Kimia sebesar 80. Namun demikian, hasil ulangan harian materi Kimia Asam-Basa kelas XI IPA 1 menunjukkan bahwa peserta didik yang mencapai KKM hanya 12 orang saja $(33,33 \%)$ dari 36 peserta didik yang ada di kelas tersebut. Observasi menunjukkan bahwa keaktifan peserta didik dalam pembelajaran tergolong rendah, kebanyakan peserta didik tidak memanfaatkan kesempatan bertanya yang diberikan oleh guru.

\footnotetext{
${ }^{1}$ Corresponding author: sarinemsih2208@gmail.com
} 
Efektifitas pembelajaran salah satunya ditentukan oleh strategi yang digunakan (Aswan dan Syaiful, 2013). Strategi pembelajaran yang baik dapat meningkatkan partisipasi aktif peserta didik dalam pembelajaran. Salah satu strategi pembelajaran yang dapat mengaktifkan peserta didik adalah College Ball. Strategi pembelajaran College Ball dapat meningkatkan motivasi belajar dan meningkatkan pemahaman peserta didik. Strategi College Ball dirancang untuk menguatkan kembali dan mengklarifikasi poin-poin kunci pembelajaran yang diajarkan di kelas (Silberman,2018). Strategi ini mampu mengaktifkan peserta didik baik secara langsung maupun tidak langsung (Nurhalimah, 2011). Prosedur pelaksanaan strategi pembelajaran college ball adalah sebagai berikut:

1. Mengelompokkan peserta didik ke dalam tim-tim kecil yang terdiri atas tiga atau empat anggota. Masing-masing tim diminta memilih dan menggunakan nama kimia (misalnya: asam-basa, hidrokarbon, penyangga dan lain-lain).

2. Memberi kartu indeks kepada setiap peserta didik. Peserta didik memegang kartunya untuk menunjukkan bahwa mereka menginginkan kesempatan untuk menyampaikan pertanyaan. Format permainan adalah undian: Setiap anggota tim dapat menunjukkan keinginan untuk menjawab.

3. Menjelaskan aturan-aturan permainan berikut:

a. Untuk menjawab pertanyaan setiap peserta harus mengangkat kartu.

b. Jika sudah merasa mengetahui jawabannya, peserta dibolehkan mengangkat kartu meskipun pertanyaan belum selesai dibacakan. Pembacaan pertanyaan dihentikan bila sudah ada peserta yang melakukan interupsi.

c. Bila jawaban peserta poin b salah maka pembacaan pertanyaan dapat dilanjutkan sampai selesai dan peserta lain dapat menjawabnya.

d. Setiap respon yang benar skornya adalah satu poin.

e. Setelah semua pertanyaan dilontarkan, skor setiap tim dihitung dan diumumkan pemenangnya.

f. Berdasarkan kualitas respon-respon atas pertanyaan yang dilontarkan, materi pelajaran yang kurang dipahami oleh peserta didik diidentifikasi dan dilakukan penguatan.

Strategi ini juga dapat dilakukan dengan variasi berikut:

a. Setiap tim dibuatkan alternatif pertanyaan sendiri-sendiri sebagai pengganti format undian.

b. Permainan ini lebih utama digunakan untuk mengases kemampuan peserta didik dalam menjelaskan keterampilan daripada menjelaskan pengetahuan (Silberman, 2018).

Strategi pembelajaran aktif tipe college ball mempunyai beberapa keunggulan, di antaranya adalah: dapat dirancang berpusat pada peserta didik, dapat mengaktifkan peserta didik dalam pembelajaran, tercipta suasana yang menyenangkan, meningkatkan kesediaan dan kesiapan peserta didik dalam belajar, serta menjadikan anak didik mampu mempertahankan stimulus dalam memori jangka panjang.

Penelitian ini bertujuan untuk menerapkan strategi pembelajaran aktif College Ball dalam meningkatkan aktivitas dan hasil belajar peserta didik dalam pembelajaran kesetimbangan ion dan $\mathrm{pH}$ larutan penyangga.

\section{METODE}

Penelitian ini menerapkan rancangan penelitian tindakan kelas. Penelitian dilaksanakan di kelas XI IPA 1 pada salah satu SMAN di Pekanbaru semester genap tahun ajaran 2018/2019. Subjek penelitian ini adalah 36 peserta didik yang terdiri atas 23 orang perempuan dan 13 orang laki-laki. Implementasi tindakan dilaksanakan pada bulan Februari-April 2019. Tindakan dilakukan dalam 3 siklus (Gambar 1). Setiap siklus terdiri atas dua kali pertemuan. Siklus I mempelajari sifat larutan penyangga (pertemuan 1) dan prinsip kerja larutan penyangga (pertemuan 2). Siklus II mempelajari pembuatan larutan penyangga (pertemuan 3 ) dan menghitung $\mathrm{pH}$ larutan penyangga (pertemuan 
4). Sedangkan siklus III mempelajari perhitungan $\mathrm{pH}$ larutan penyangga (pertmuan 5) dan peranan larutan penyangga dalam tubuh makhluk hidup (pertmuan 6).

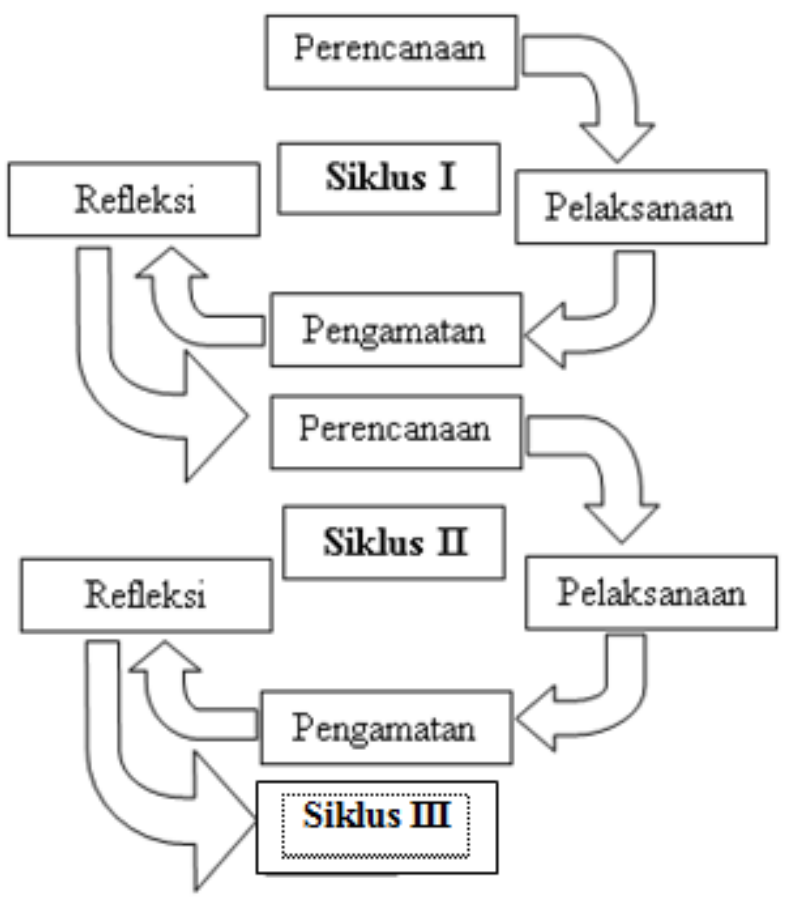

Gambar 1. Rancangan penelitian tindakan kelas (Arikunto, 2015)

Instrumen yang digunakan dalam penelitian ini meliputi instrumen pembelajaran dan instrumen penngumpulan data. Instrumen pembelajaran yang digunakan adalah silabus, rencana pelaksanaan pembelajaran (RPP), lembar kegiatan peserta didik, dan soal College Ball. Instrumen pengumpulan data menggunakan lembar observasi guru, lembar observasi peserta didik, soal evaluasi setiap pertemuan dan soal ulangan harian setiap akhir siklus.

Data yang dikumpulkan dari observasi pelaksanaan tindakan dianalisis secara deskriptif menggunakan teknik persentase. Perubahan kualitas proses dan hasil belajar peserta didik yang merupakan efek penerapan strategi pembelajaran dianalisis menggunakan perubahan persentase (Kunandar, 2011).

Tabel 1. Kriteria Keberhasilan Tindakan

\begin{tabular}{clc}
\hline Kriteria & \multicolumn{1}{c}{ Indikator keberhasilan tindakan } \\
\hline Aktivitas belajar peserta didik & a. $\geq 60 \%$ peserta didik aktif merespom pertanyaan guru membuka pembelajaran \\
& b. $\geq 50 \%$ peserta didik aktif mengarahkan diri untuk duduk di dalam kelompok \\
& d. $\geq 60 \%$ peserta didik memeperhatikan PPT yang ditampilkan guru \\
& e. $\geq 60 \%$ peserta didik aktif berdiskusi mengerjakan LKPD \\
& f. $\geq 70 \%$ peserta didik aktif menyampaikan pendapat \\
& g. $\geq 60 \%$ peserta didik antusias terhadap permainan College Ball \\
& h. $\geq 60 \%$ peserta didik termotivasi menjawab soal College Ball \\
& i. $\geq 60 \%$ peserta didik ikut dalam aktivitas penutup pembelajaran \\
\hline Rata-rata kesembilan indikator & \\
\hline Hasil belajar &
\end{tabular}




\section{HASIL DAN PEMBAHASAN}

\section{Hasil}

Persentase hasil belajar peserta didik setiap siklus dapat dilihat pada Gambar 2 di bawah ini.

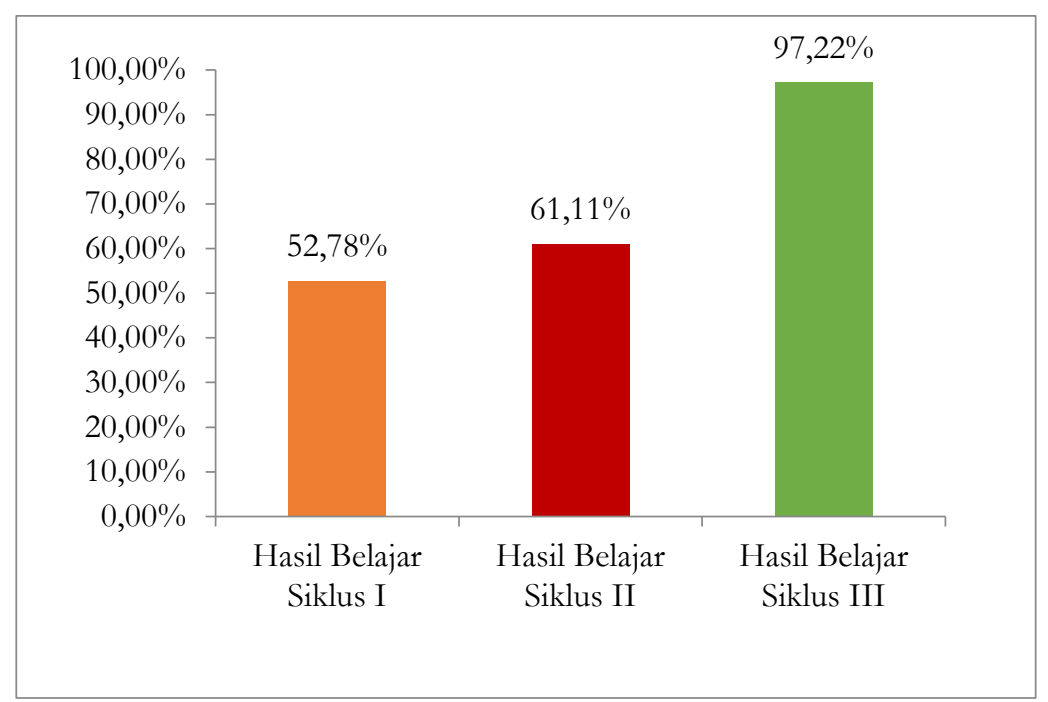

Gambar 2. Hasil Belajar Peserta Setiap Siklus

Adapun data hasil rekapitulasi observasi aktivitas guru, dan aktivitas peserta didik selama 3 siklus pada materi kesetimbangan ion dan $\mathrm{pH}$ larutan penyangga dapat dilihat pada Tabel 2 dan 3 . Hasil belajar peserta didik diperoleh dari ulangan harian setiap siklus, untuk ketuntasan belajar klasikal peserta didik siklus 1, 2 dan 3 dapat dilihat pada Tabel 4-6.

Tabel 2. Hasil Rekapitulasi Aktivitas Guru

\begin{tabular}{|c|c|c|c|c|c|c|c|c|c|}
\hline \multirow{4}{*}{ Indikator } & \multicolumn{9}{|c|}{$\%$ Aktivitas Guru } \\
\hline & \multicolumn{3}{|c|}{ Siklus I } & \multicolumn{3}{|c|}{ Siklus II } & \multicolumn{3}{|c|}{ Siklus III } \\
\hline & \multicolumn{2}{|c|}{$\begin{array}{l}\text { Pertemuan } \\
\text { ke }\end{array}$} & \multirow[t]{2}{*}{ Rerata } & \multicolumn{2}{|c|}{$\begin{array}{c}\text { Pertemuan } \\
\text { ke }\end{array}$} & \multirow[t]{2}{*}{ Rerata } & \multicolumn{2}{|c|}{$\begin{array}{c}\text { Pertemuan } \\
\text { ke }\end{array}$} & \multirow[t]{2}{*}{ Rerata } \\
\hline & 1 & 2 & & 3 & 4 & & 5 & 6 & \\
\hline 1. Membuka Pelajaran & 3 & 4 & 3,5 & 4 & 4 & 4 & 4 & 4 & 4 \\
\hline $\begin{array}{l}\text { 2. Mengorganisasikan peserta didik } \\
\text { dalam kelompok }\end{array}$ & 4 & 4 & 4 & 4 & 4 & 4 & 4 & 4 & 4 \\
\hline $\begin{array}{l}\text { 3. Menampilkan media pembelajaran } \\
\text { PPT }\end{array}$ & 3 & 3 & 3 & 1 & 4 & 2,5 & 4 & 4 & 4 \\
\hline 4. Memberikan kesempatan bertanya & 4 & 4 & 4 & 4 & 4 & 4 & 4 & 4 & 4 \\
\hline 5. Membimbing diskusi kelompok & 3 & 3 & 3 & 3 & 4 & 3,5 & 3 & 4 & 3,5 \\
\hline 6. Membimbing presentasi kelompok & 3 & 3 & 3 & 3 & 3 & 3 & 3 & 4 & 3,5 \\
\hline $\begin{array}{l}\text { 7. Menerapkan strategi pembelajaran } \\
\text { aktif College Ball }\end{array}$ & 2 & 2 & 2 & 2 & 3 & 2,5 & 3 & 4 & 3,5 \\
\hline $\begin{array}{l}\text { 8. Memotivasi menjawab soal College } \\
\text { Ball }\end{array}$ & 4 & 4 & 4 & 4 & 4 & 4 & 4 & 4 & 4 \\
\hline 9. Menutup pembelajaran & 3 & 3 & 3 & 3 & 3 & 3 & 4 & 4 & 4 \\
\hline Jumlah & 29 & 30 & 29,5 & 28 & 33 & 30,5 & 33 & 36 & 34,5 \\
\hline Rerata & 80,56 & 83,33 & 81,94 & 77,78 & 91,67 & 84,72 & 91,67 & 100 & 95,83 \\
\hline Kategori & B & B & B & B & $\mathbf{A}$ & B & A & $\mathbf{A}$ & $\mathbf{A}$ \\
\hline
\end{tabular}


Tabel 3. Hasil Rekapitulasi Aktivitas Belajar Peserta Didik

\begin{tabular}{|c|c|c|c|c|c|c|c|c|c|}
\hline \multirow{4}{*}{ Indikator } & \multicolumn{9}{|c|}{ \% Aktivitas Peserta Didik } \\
\hline & \multicolumn{3}{|c|}{ Siklus I } & \multicolumn{3}{|c|}{ Siklus II } & \multicolumn{3}{|c|}{ Siklus III } \\
\hline & \multicolumn{2}{|c|}{ Pertemuan ke } & \multirow{2}{*}{ Rerata } & \multicolumn{2}{|c|}{ Pertemuan ke } & \multirow{2}{*}{ Rerata } & \multicolumn{2}{|c|}{ Pertemuan ke } & \multirow{2}{*}{ Rerata } \\
\hline & 1 & 2 & & 3 & 4 & & 5 & 6 & \\
\hline $\mathrm{I}$ & 65,97 & 69,44 & 67,71 & 78,47 & 82,64 & 80,55 & 88,19 & 88,20 & 88,19 \\
\hline II & 71,53 & 77,08 & 74,31 & 88,20 & 100 & 94,10 & 100 & 100 & 100 \\
\hline III & 68,06 & 68,06 & 68,06 & 70,80 & 83,33 & 77,07 & 87,50 & 88,00 & 87,75 \\
\hline IV & 45,14 & 47,92 & 46,53 & 49,30 & 60,42 & 54,86 & 62,50 & 70,83 & 66,67 \\
\hline $\mathrm{V}$ & 64,58 & 67,36 & 65,97 & 68,10 & 70,14 & 69,12 & 78,47 & 78,50 & 78,49 \\
\hline VI & 44,44 & 44,44 & 44,44 & 49,30 & 62,50 & 55,90 & 68,06 & 72,22 & 70,14 \\
\hline VII & 72,92 & 72,92 & 72,92 & 74,30 & 74,31 & 74,31 & 74,31 & 74,31 & 74,31 \\
\hline VIII & 65,97 & 66,67 & 66,32 & 66,70 & 67,36 & 67,03 & 70,14 & 70,83 & 70,48 \\
\hline IX & 76,34 & 76,39 & 76,37 & 77,10 & 77,10 & 77,10 & 78,47 & 81,25 & 79,30 \\
\hline Rerata & 63,88 & 65,59 & 64,74 & 69,14 & 75,31 & 72,23 & 78,32 & 80,14 & 79,17 \\
\hline Kategori & B & $\mathrm{B}$ & $\mathrm{B}$ & B & $\mathrm{B}$ & B & B & B & B \\
\hline
\end{tabular}

Tabel 4. Tingkat Ketuntasan Belajar Larutan Penyangga Peserta Didik pada Siklus I, II, dan III

\begin{tabular}{lccc}
\hline & \multicolumn{3}{c}{ Jumlah Peserta Didik } \\
\hline Tingkat Ketuntasan & Siklus I & Siklus II & Siklus III \\
\hline Tuntas & 19 & 22 & 35 \\
Tidak tuntas & 17 & 14 & 1 \\
\hline Nilai rata-rata peserta didik & 79.11 & 80,21 & 88,15 \\
$\%$ Ketuntasan klasikal & $52.78 \%$ & $61,11 \%$ & $97,22 \%$ \\
\hline
\end{tabular}

\section{Pembahasan}

Tabel 2 menunjukkan bahwa pada siklus I persentase rata-rata aktivitas guru adalah 81,94\%. Refleksi dan diskusi bersama observer mengenai proses dan hasil siklus I menyepakati beberapa perbaikan yang dilaksanakan pada siklus II, yakni: (1) mengatur waktu agar pelaksanaan strategi pembelajaran College Ball terlaksana dengan baik, (2) menjelaskan kembali langkah-langkah dan aturan-aturan strategi pembelajaran College Ball, dan (3) memberikan nilai tersendiri kepada peserta didik yang bertanya. Penerapan perbaikan-perbaikan ini pada siklus II meningkatkan aktivitas guru menjadi $84,72 \%$. Refleksi terhadap pembelajaran siklus II juga menyepakakati beberapa hal, yaitu: (1) memilih peserta didik secara acak untuk bertanya dan menyampaikan pendapat agar seluruh peserta didik siap untuk menyampaikan pertanyaan dan (2) guru menumbuhkan rasa ingin tahu dan motivasi peserta didik untuk bertanya dengan cara memberikan nilai tersendiri kepada peserta didik yang bertanya. Perbaikan ini meningkatkan aktivitas guru pada siklus III menjadi 95,83\% dengan kategori sangat baik.

Aktivitas belajar peserta didik diamati menggunakan sembilan indikator (Tabel 3), yaitu: (1) respon peserta didik ketika guru membuka pembelajaran, (2) mengorganisasikan diri dalam kelompok, (3) memperhatikan PPT yang ditampilkan guru, (4) mengajukan pertanyaan, (5) berdiskusi dalam kelompok untuk mengerjakan LKPD, (6) menyampaikan jawaban/pendapat, (7) antusias terhadap permainan College Ball, (8) termotivasi menjawab soal College Ball, dan (9) menyimpulkan pembelajaran serta mengerjakan evaluasi. Pada siklus I banyak peserta didik yang belum termotivasi untuk mengikuti pembelajaran serta banyak yang belum paham mengenai tatacara dan aturanaturan strategi pembelajaran College Ball sehingga persentase rata-rata aktivitas peserta didik pada siklus I adalah sebesar 64,74\%, adapun indikator yang masih dibawah pencapaian yang diharapkan 
adalah aktivitas bertanya yaitu sebesar 46,53\%dan menyampaikan pendapat 44,44\% setelah dilakukannya refleksi pada pada siklus I dan merencanakan tindakan perbaikan pada siklus selanjutnya, aktivitas peserta didik meningkat menjadi 72,23\% pada siklus II indikator aktivitas peserta didik bertanya dan menjawab pertanyaan berturut-turut adalah sebesar 54,86\% dan 55,9\% sedangkan persentase siklus III sebesar $79,17 \%$ indikator aktivitas bertanya dan menjawab pertanyaan sudah mencapai kriteria yang diharapkan. Menurut Sadirman (2012) aktivitas belajar merupakan hal penting dalam pembelajaran, tanpa adanya aktivitas maka proses pembelajaran tidak akan berlangsung dengan baik. Hal-hal yang dilakukan peserta didik selama proses pembelajaran akan menjadi sebuah pengalaman belajar, contoh aktivitas peserta didik didalam kelas adalah menegrjakan latihan-latihan soal, semakin banyak soal-soal yang dibahas maka akan semakin paham dan hal ini dapat memudahkan peserta didik menjawab soal-soal yang di diberikan guru, sehingga mencapai kriteria ketuntasan minimum yang diharapkan

Hasil belajar peserta didik yang terdapat pada tabel 3 diperoleh dari nilai Ulangan Harian (UH) pada, Ketuntasan belajar klasikal belum mencapai kriteria keberhasilan tindakan yang telah ditetapkan yaitu 70\%. Aktivitas belajar peserta didik yang baik sejalan dengan hasil belajar yang diperoleh peserta didik. Hasil belajar peserta didik yang diperoleh dari UH siklus II meningkat dari siklus I, dari 36 peserta didik sebanyak 22 peserta didik telah mecapai KKM, sedangkan 14 orang peserta didik yang tidak mencapai nilai KKM. Ketuntasan belajar klasikal peserta didik pada siklus II 61,11\% dengan rata-rata 80,21. Ketuntasan belajar peserta didik masih belum mencapai kriteria keberhasilan tindakan yang ditetapkan. Hasil belajar peserta didik yang diperoleh dari UH siklus III meningkat dari siklus II, dari 36 peserta didik sebanyak 35 peserta didik telah mecapai KKM, sedangkan 1 orang peserta didik yang tidak mencapai nilai KKM. Ketuntasan belajar klasikal peserta didik pada siklus III 97,22\% dengan rata-rata 88,15. Ketuntasan belajar peserta didik sudah mencapai kriteria keberhasilan tindakan yang ditetapkan ketuntatasan belajar ini berhasil dikarenakan peserta didik aktif dalam mengikuti proses pembelajaran.

Wina Sanjaya (2013) menyatakan bahwa keterlibatan peserta didik selama proses pembelajaran melalui interaksi peserta didik dengan peserta didik maupun peserta didik dengan guru dapat meningkatkan aktivitas dan hasil belajar peserta didik.

\section{KESIMPULAN}

Berdasarkan hasil penelitian dan pembahasan yang telah diluraikan dapat disimpulkan bahwa strategi pembelajaran aktif College Ball dapat meningkatkan aktifitas dan hasil belajar peserta didik dalam mempelajari materi larutan penyangga.

\section{DAFTAR RUJUKAN}

Dina Novarina Perdana. 2018. Penerapan Kooperatif Tipe Tgt Dengan Strategi College Ball Pada Pembelajaran Matematika Siswa Kelas XI IPA SMAN I X Koto Singkarak. Journal of RESIDU, Volume 2, Issue 10, Oktober 2018 hal 1-7.

Djamarah dan Zain. 2013. Strategi Belajar Mengajar. Rineka Cipta. Jakarta.

Hartono. 2011. PAIKEM Pembelajaran Aktif Inovatif Kreatif Efektif dan Menyenangkan. Zanafa Publishing. Riau.

Imah Nurhalimah. 2011. Upaya Meningkatkan Hasil Belajar Sejarah Siswa Kelas XI IPS 1 SMA N 1 Ciwaringin Cirebon Melalui Strategi Pembelajaran Aktif Tipe College Ball. Skripsi tidak dipublikasikan.FIS Universitas Negeri Semarang. Semarang.

Jamil Suprihatiningrum. 2016. Strategi Pembelajaran Teori dan Aplikasi. Ar-Ruzman Media. Yogyakarta.

Kunandar. 2011. Langkah Mudah Penelitian Tindakan Kelas Sebagai Pengembangan Profesi Guru. Rajawali Press. Jakarta. 
Mel, Silberman. 2018. Active Learning 101 Strategi Pembelajaran Aktif. Pustaka Insan Madani. Yogyakarta Sardiman A.M. 2012. Interaksi dan Motivasi Belajar Mengajar. Raja Grafindo Persada. Jakarta.

Sanjaya, W. 2013. Perencanaan dan Desain Sistem Pembelajaran. Kencana. Jakarta.

Sudijono, Anas. 2006. Pengantar Evaluasi Pendidikan. Raja Grafindo Persada. Jakarta.

Suharsimi Arikunto. 2010. Penelitian Tindakan Kelas. Bumi Aksara. Jakarta. 